\title{
ESTUDO DA CORRELAÇÃO ENTRE CRISTALÚRIA E INFECÇÃO URINÁRIA EM PORCAS GESTANTES G.C. ALBERTON ${ }^{1}$; P.R. WERNER ${ }^{2}$; J. SOBESTIANSKY ${ }^{3}$ \\ ${ }^{1}$ Universidade Federal do Paraná. ${ }^{2}$ Universidade Paranaense - UNIPAR, Umuarama-PR. ${ }^{3}$ Universidade Federal de Goiás.
}

De acordo com informações da literatura, a cristalúria constitui-se num importante fator predisponente para infecção urinária (IU), pois os cristais presentes na urina irritam a mucosa do trato urinário, criando um sítio para crescimento bacteriano. Este trabalho teve como objetivo verificar se existe correlação entre cristalúria e IU e verificar a prevalência e os tipos de cristais presentes na urina de porcas gestantes. Colheu-se por meio de micção espontânea, a urina de 1623 porcas gestantes provenientes de 25 granjas da região Sul do Brasil. As amostras de urina foram centrifugadas à $1500 \mathrm{rpm}$ durante 5 minutos e do sedimento urinário fez-se uma análise qualitativa e quantitativa dos cristais encontrados. O diagnóstico de IU e a mensuração do $\mathrm{pH}$ urinário foram conduzidos com auxílio de tiras reagentes*, sendo consideradas portadoras de IU as porcas que apresentaram nitrito e/ou sangue na urina. Os dados obtidos foram analisados no programa estatístico Statistical Analysis System (SAS). Das 1623 amostras de urina analisadas, $891(55 \%)$ apresentavam cristais no sedimento. Não se observou correlação $(\mathrm{p}=$ $0,476)$ entre cristalúria e IU, sendo muito próximos os valores de prevalência de IU para as porcas com cristalúria $(27,50 \%)$ e sem cristalúria $(29,10 \%)$. Os tipos de cristais e a freqüência com que eles foram encontrados nas amostras de urina foram: fostato triplo - $26 \%$; oxalato de cálcio - $22 \%$; urato amorfo - $22 \%$; fosfato amorfo - $5 \%$ e sulfato de cálcio $-1,4 \%$. Observou-se maior freqüência de cristalúria nas porcas que apresentavam urina alcalina, sendo que das 260 porcas que apresentaram urina com pH maior que $7.3,170(65,38 \%)$ continham cristais na urina. Os tipos de cristais encontrados e a sua incidência foram semelhantes ao relatado por outros autores. Com base nos resultados desta pesquisa, pode-se concluir que a cristalúria em porcas gestantes é um achado clínico comum e que não apresenta correlação com infecção urinária.

*Rapignost ${ }^{\circledR}$ Basis Screen plus - Behring - Alemanha 